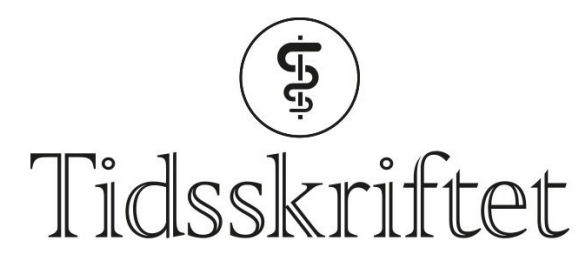

DEN NORSKE LEGEFORENING

\title{
Mann i 2o-årene med svimmelhet, dobbeltsyn og perifer facialisparese
}

NOE Å LAERE AV

INGRID ANNE LIE

E-post: ingridanne.lie@gmail.com

Nevrologisk avdeling

Haukeland universitetssykehus

Ingrid Anne Lie er lege i spesialisering.

Forfatter har fylt ut ICMJE-skjemaet og oppgir ingen interessekonflikter.

\section{BJØRN BLOMBERG}

Nasjonalt kompetansesenter for tropiske infeksjonssykdommer

og

Infeksjonsseksjonen

Medisinsk avdeling

Haukeland universitetssykehus

og

Klinisk institutt 2

Universitetet i Bergen

Bjørn Blomberg er ph.d., spesialist i indremedisin og i infeksjonssykdommer og er overlege.

Forfatter har fylt ut ICMJE-skjemaet og oppgir ingen interessekonflikter.

\section{ØYSTEIN ALEXANDER POWER}

Infeksjonsseksjonen

Medisinsk avdeling

Haukeland universitetssykehus

$\emptyset$ ystein Alexander Power er spesialist i indremedisin og i infeksjonssykdommer og er overlege.

Forfatter har fylt ut ICMJE-skjemaet og oppgir følgende interessekonflikter: Han har mottatt foredragshonorar fra GlaxoSmithKline.

\section{ØIVIND TORKILDSEN}

Nevrologisk avdeling

Haukeland universitetssykehus

og

Klinisk institutt 1

Universitetet i Bergen

Øivind Torkildsen er ph.d., spesialist i nevrologi og overlege.

Forfatter har fylt ut ICMJE-skjemaet og oppgir ingen interessekonflikter.

Svimmelhet og ustøhet er uspesifikke symptomer som ofte vil være forårsaket av forstyrrelser i balanseapparatet. Når pasientene i tillegg har nevrologiske funn, bør man imidlertid tenke på sykdommer i resten av nervesystemet. Disse symptomene kan være tegn på alvorlig systemisk sykdom, noe denne kasuistikken illustrerer. 
En mann i slutten av 20-årene kontaktet sin fastlege da han i noen dager hadde følt seg $\emptyset$ kende svimmel og ustø. Fastlegen mistenkte benign paroksysmal posisjonsvertigo, men selv etter behandlingsfors $ø \mathrm{k}$ med Epleys manøver, hadde pasienten vedvarende symptomer. To måneder etter første kontakt med fastlege fikk han i tillegg gradvis innsettende høyresidig facialisparese, dobbeltsyn, hodepine og øresus. Han ble derfor henvist akutt til vurdering ved øre-nese-hals-avdeling. Ved klinisk undersøkelse ble det funnet perifer facialisparese, ellers ingen andre sikre patologiske funn. På mistanke om Bells parese startet man poliklinisk en kur med prednisolon 6o mg x 1 i fem dager, før nedtrapping med $10 \mathrm{mg}$ daglig til seponering. I tillegg ble det tatt borreliaserologi. Pasienten følte seg ustø og hadde hodepine og han ble derfor henvist til en poliklinisk MRundersøkelse av hodet. Da blodprøvene etter få dager viste positiv serologi for IgMborreliaantistoff valgte man å legge til doksycyklin $100 \mathrm{mg}$ to tabletter daglig i 14 dager for behandling av mulig nevroborreliose. Prøvene var negative for IgG-borreliaantistoffer, så mistanken om nevroborreliose var imidlertid liten.

Den vanligste årsaken til isolert $\emptyset \mathrm{kning}$ i IgM-borreliaantistoff er uspesifikk reaktivitet. Ved borreliose kan tester for IgG- og IgM-borreliaantistoffer være negative tidlig i sykdomsforløpet. Vanligvis er det anbefalt å kontrollere serologi etter 6-8 uker.

Pasienten anga ved telefonisk kontakt med øre-nese-hals-avdelingen rask symptombedring. Dobbeltsynet og hodepinen forsvant, og facialisparesen gikk delvis i regress. Symptomene residiverte imidlertid en uke etter seponering av systemiske steroider, og han ble innlagt akutt i nevrologisk avdeling med spørsmål om nevroborreliose. MR-unders $ø$ kelsen av hodet var enda ikke tatt. Ved innleggelsen hadde pasienten relativt god allmenntilstand og kunne gjøre godt rede for sykehistorien. Hans foreldre var opprinnelig fra Sørøst-Asia, men han var selv født og oppvokst i Norge. Pasienten kjente ikke til nevrologiske sykdommer hos nære slektninger.

Ved nevrologisk undersøkelse fant man ataktiske følgebevegelser med øynene, horisontal og vertikal nystagmus, høyresidig abducensparese og perifer facialisparese. Gangen var ust $\varnothing$ og ataktisk, med falltendens mot høyre, forenlig med lillehjerneaffeksjon. Det var ellers normal sensibilitet, motorikk og reflekser. Alle vitale parametere var normale, og det var ingen funn ved undersøkelse av hjerte, lunger eller abdomen. Orienterende blodprøver var normale, inkludert leukocytter, CRP og senkning. Borreliaserologi ble gjentatt og var uendret, med positiv test for IgM-antistoffer og negativ for IgG-antistoffer.

Gradvis debut av symptomer med et subakutt forløp og symptombedring under behandling med steroider gjorde at aktuelle differensialdiagnoser i den initiale utredningen først og fremst var inflammatoriske, infeksiøse eller ekspansive tilstander. Nevroborreliose ble vurdert som mindre sannsynlig ut fra serologien og manglende effekt av doksycyklin. For å avdekke patologi som krever øyeblikkelige tiltak, for eksempel tumor med uttalt hevelse, er cerebral computertomografi (CT) en rask og lett tilgjengelig undersøkelse.

CT-undersøkelse uten kontrast av hodet ble tatt umiddelbart etter innleggelse og viste lavattenuerende forandringer i hvit substans frontalt i høyre storhjernehemisfære (fig 1) og i høyre lillehjernehemisfære. Supplerende magnetisk resonanstomografi av hjerne og medulla påfølgende dag avdekket multiple lesjoner i hjernestamme, lillehjerne og begge storhjernehemisfærer (fig 2). Nevroradiolog vurderte funn som forenlig med multiple metastaser, hjernetuberkulose, parasittsykdom eller septiske embolier med sekundær abscessdanninger. Spinalvæskeundersøkelse viste leukocyttnivå på $9 \cdot 10^{9} / 1$, men ellers normale verdier for erytrocytter, glukose og protein. Det ble samme kveld utført CT av thorax, abdomen og bekken for å se etter tegn til ekstracerebral sykdom, inkludert kreft, bakterielt infeksjonsfokus, tuberkulose i eller utenfor lunger, eventuelt tegn til parasittsykdom. Denne avdekket multiple mikronoduli i lungene, mest i apikale deler av begge overlappene, én litt større nodulus apikalt og lateralt i venstre overlapp samt en liten høyattenuerende lesjon til høyre for avgangen av høyre hovedbronkus som var forenlig med en forkalket lymfeknute (fig 3 ). Det var multiple lavattenuerende lesjoner i abdomen 
og bekken, mest i øvre del av lever, og i tillegg lesjoner i nyre og prostata. Radiologen beskrev funnene som mest forenlig med miliær tuberkulose.

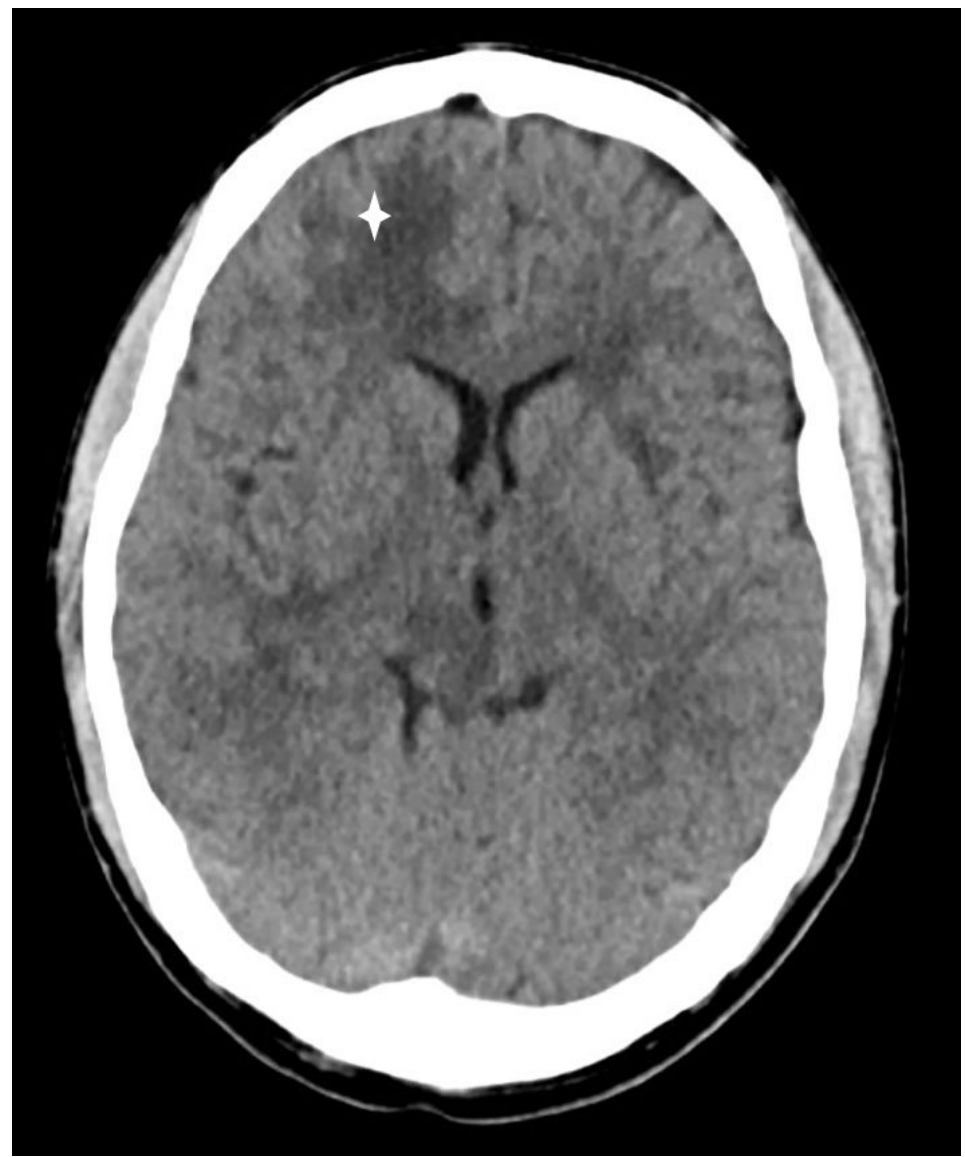

Figur 1 CT caput uten konstrastmiddel viser lavattenuerende forandringer $i$ hit substans frontalt $i$ høyre storhjernehemisfcere (stjerne). 


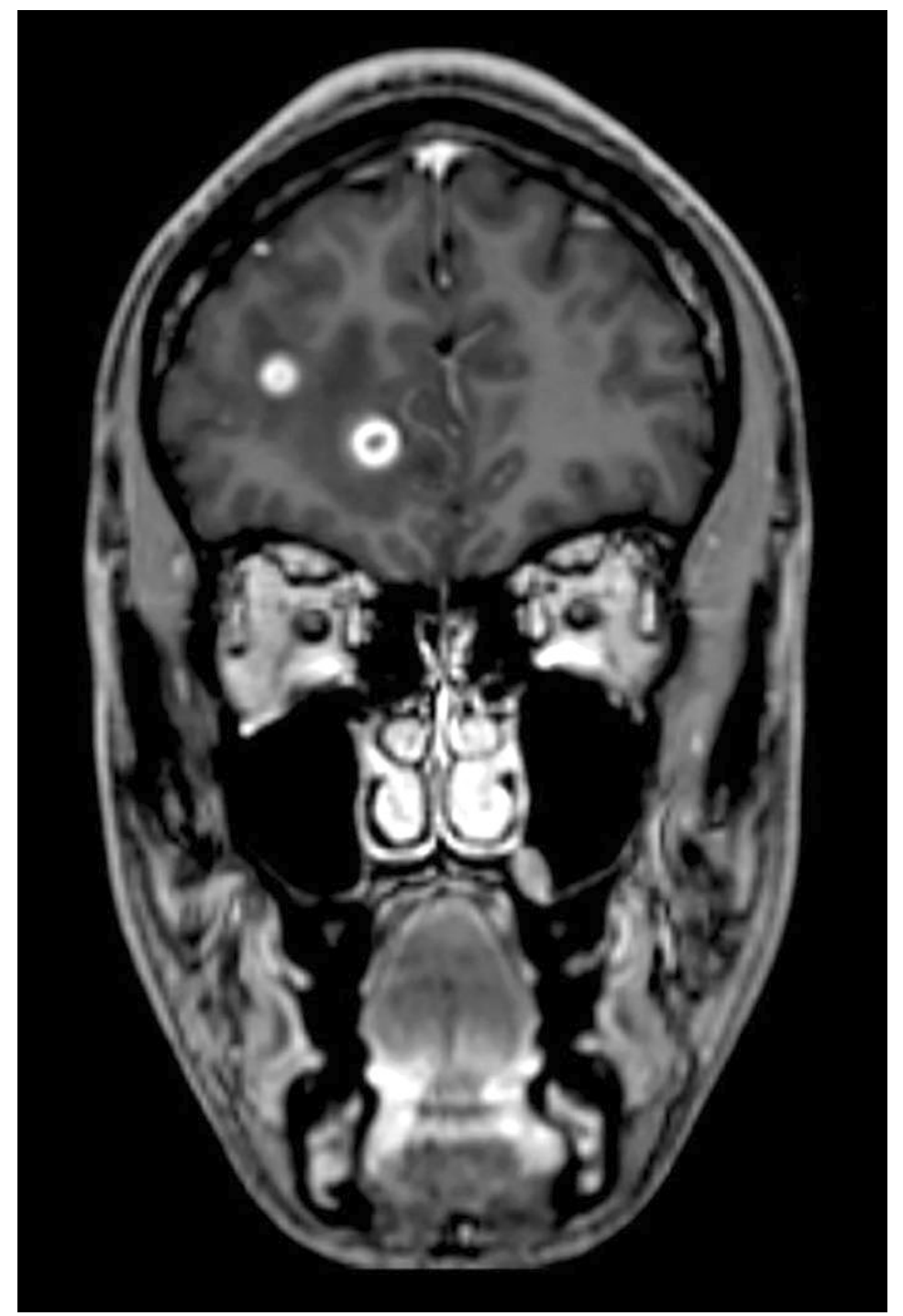

Figur 2 T1-vektet volumetrisk magnetisk resonanstomografi av hjerne og medulla, tatt med kontrastmiddel. Bildet viser multiple lesjoner i storhjernehemisfaren.

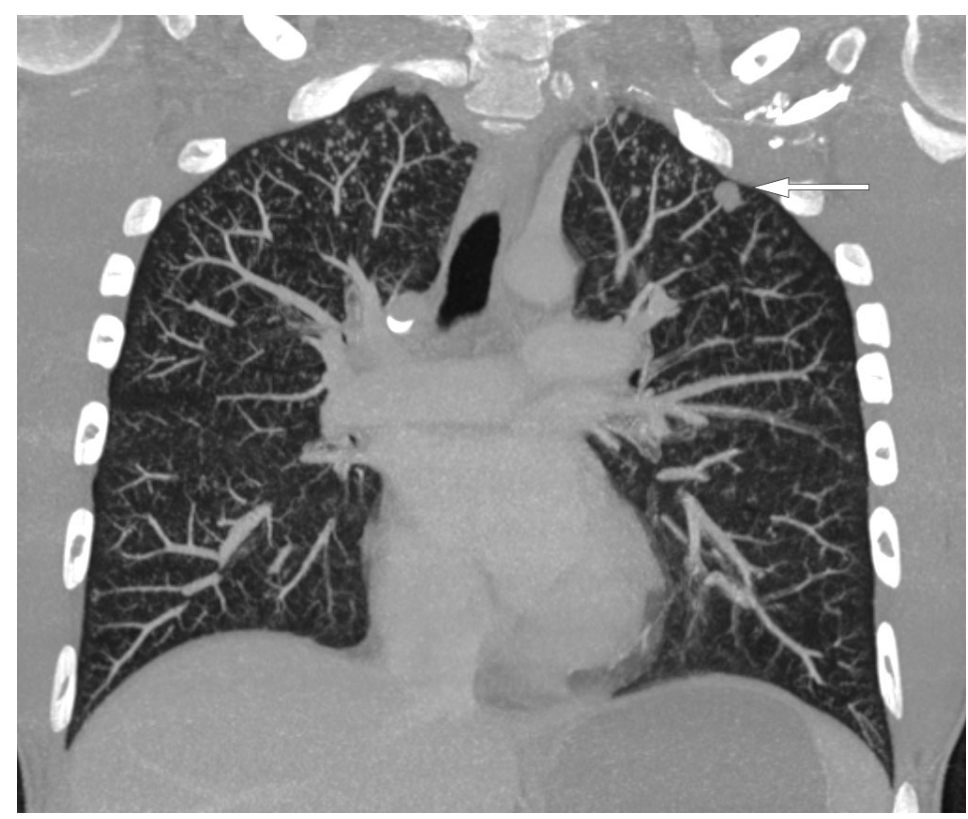

Figur $_{3}$ CT thorax tatt etter injeksjon av intavenøst kontrastmiddel. Bildet viser multiple mikronoduli i begge lungetopper og en $9 \mathrm{~mm}$ nodulus apikalt og lateralt $i$ venstre overlapp (pil).

Tuberkulosebakterier overføres via luftsmitte. Dersom kroppens immunforsvar ikke bekjemper infeksjonen, vil det i lungene dannes et granulom eller en tuberkel gjennom en inflammatorisk prosess. Dette kalles et primærfokus. Et primærfokus med tilhørende 
tuberkuloseinfiserte hilusglandler danner et primærkompleks. Herfra kan bakteriene spres via blodbanen. I de fleste tilfeller vil immunforsvaret hindre videre spredning, men bakteriene kan også overleve i lang tid. Tilstanden kalles da latent tuberkulose, noe som per definisjon ikke gir symptomer. Hos ellers immunfriske pasienter vil 9o-95\% av de som blir infisert kun få latent tuberkulose, mens 5-10 \% utvikler aktiv sykdom. Blant de med aktiv sykdom vil de fleste utvikle lungetuberkulose, men rundt en firedel til en tredel vil få ekstrapulmonal tuberkulose. Ved disseminert eller miliær tuberkulose kan infeksjonen spres via blodbanen til alle deler av kroppen. Vår pasient hadde lesjoner i

sentralnervesystemet, lunger, lever, nyrer og prostata som kunne passe med hematogen spredning av tuberkulose.

Grunnet mistanke om potensielt smitteførende tuberkulose ble pasienten flyttet til luftsmitteisolat ved infeksjonsmedisinsk seksjon. Nærmere gjennomgang av anamnesen avslørte noe vekttap og nattesvette den siste tiden, men ingen hoste, tungpustethet eller feberfølelse. Pasienten oppga at han hadde oppholdt seg 2-3 måneder i foreldrenes hjemland i Sørøst-Asia seks måneder før symptomdebut. Han hadde fått BCG-vaksine som barn. Som videre ledd i tuberkulosediagnostikken ble det tatt repeterte prøver av saltvannsindusert ekspektorat, bronkoskopi med bronkial skylleprøve samt mykobakteriedyrkning av urin og avføring. Selv om man enda ikke hadde sikre holdepunkter for tuberkulose, ble det etter bronkoskopi startet antituberkuløs behandling med intravenøs rifampicin og peroral isoniazid, pyrazinamid og etambutol med doser som anbefalt i tuberkuloseveilederen (1). Initialt valgte vi å legge til høydose moksifloksacin $800 \mathrm{mg} \times 1$ med tanke på bedret penetrasjon til sentralnervesystemet. I tillegg til den antituberkuløse behandlingen startet man deksametason $12 \mathrm{mg}$ x 1 for å dempe hevelse i hjernen.

Vanlig tuberkulosebehandling er delt inn i en intensivfase med rifampicin, isoniazid, pyrazinamid og etambutol $i$ to måneder og deretter en kontinuasjonsfase med rifampicin og isoniazid i fire måneder (1). Ved tuberkulose i sentralnervesystemet, særlig ved tuberkuløs meningitt, forlenges vanligvis kontinuasjonsfasen, slik at total behandlingstid blir 12 måneder. Isoniazid penetrerer fritt til spinalvæske og har sterk baktericid effekt gjennom hele behandlingsforløpet (2). Rifampicin har dårlig penetrasjon til spinalvæske, men har potent antituberkuløs virkning og regnes som en hjørnestein i behandling av all tuberkulose, også i sentralnervesystemet (3). Pyrazinamid har god penetrasjon gjennom blod-hjerne-barrieren, mens etambutol har dårlig penetrasjon gjennom blod-hjernebarrieren.

Det ble ikke sett syrefaste staver i direkte mikroskopi av verken spinalvæske, indusert sputum eller bronkial skyllevæske. Polymerasekjedereaksjonstest (PCR) med henblikk på tuberkulosekomplekset var negativ i de samme prøvene. Mistanken om tuberkulose var imidlertid sterk, og det var indikasjon for vevsbiopsier for direkte påvisning av mykobakterier. Biopsi av lunge eller prostata ble vurdert som tryggere enn biopsi av nyre og ikke minst hjerne. Direkte mikroskopi av transurethral biopsi fra prostata og CT-veiledet transtorakal biopsi fra lunge ga negative funn. Fire dager etter prøvetakning ble det ved PCR av prostatavev påvist DNA fra mykobakterier tilhørende tuberkulosekomplekset. I tillegg var denne prøven positiv for mutasjon i rpoB-genet.

Diagnosen tuberkulose ble bekreftet ved PCR-funnet i prostatavevet. Mutasjoner i rpoBgenet er en markør for rifampicinresistens. Ved påvist rifampicinresistens er det over 9o \% sannsynlighet for samtidig isoniazidresistens. Dersom bakterien er resistent for begge disse primærmidlene, foreligger per definisjon multiresistent tuberkulose. Multiresistent tuberkulose er assosiert med dårligere prognose og $ø$ kt mortalitet. Tilstanden krever lengre behandling med medikamenter, med $ø$ kt risiko for alvorlige bivirkninger, og behandlingen er sentralisert til regionsykehusnivå.

Med forbehold om at PCR-metoden ikke var validert for det aktuelle prøvematerialet, måtte vi ta høyde for at det kunne foreligge multiresistent tuberkulose. Som anbefalt i 
tuberkuloseveilederen skiftet vi til en hyppig valgt empirisk kombinasjonsbehandling for mistenkt multiresistent tuberkulose: moksifloksacin, pyrazinamid, amikacin, cycloserin, og protionamid. Vi valgte i tillegg å beholde isoniazid i regimet til eventuell resistens ble bekreftet. Pasienten hadde allerede fått behandling i en drøy uke og følte seg bedre. Det var likevel en mulighet for at dette kunne tilskrives effekt av pyrazinamid og systemiske steroider. Etter to uker med behandling var han fortsatt ustø, men hadde nesten ingen abducens- eller facialisparese.

Resistens mot tuberkulosemidlene, særlig multiresistent tuberkulose (4), men også monoresistens mot isoniazid (2), er forbundet med økt dødelighet ved tuberkuløs meningitt. Reservemedisinene som brukes mot multiresistent tuberkulose har mye bivirkninger. Vår pasient fikk nevropsykiatriske symptomer en uke ut i behandlingen, men kom seg etter at cycloserin ble seponert.

Fire uker inn i behandlingen for mistenkt multiresistent tuberkulose tilkom vekst av tuberkulosebakterier i prøve av prostatavev. Noe overraskende viste ny PCR ingen mutasjon i rpoB-genet. Resistensbestemmelse utført ved Folkehelseinstituttet viste fenotypisk følsomhet for alle primærmidlene. Det ble ikke funnet mutasjon i rpoB eller markører for resistens mot isoniazid.

Da multiresistent tuberkulose ble avkreftet, gikk man tilbake til førstelinjebehandling. På grunn sykdommens alvorlighetsgrad samt omfattende sentralnervøs utbredelse, valgte vi å beholde tillegg av moksifloksacin gjennom intensivfasen, selv om det ikke finnes god dokumentasjon for dette valget ved tuberkulose følsom for primærmidlene. Pasienten fikk deretter kontinuasjonsbehandling med rifampicin og isoniazid i en samlet behandlingstid på 12 måneder. Etter seks uker reiste pasienten hjem fra sykehuset. Ved utreise var det fullstendig tilbakegang av hjernenerveutfallene, men han var fortsatt noe ust $\varnothing$ ved gange. Det ble ikke funnet vekst av mykobakterier i øvrige prøver tatt fra luftveier, og vi vurderte pasienten som ikke-smitteførende. Det var heller ikke vekst i urin, avføring eller spinalvæske. Hadde multiresistent tuberkulose blitt påvist, ville pasienten vanligvis ha blitt isolert inntil tre dyrkningsprøver var negative.

\section{Diskusjon}

Kasuistikken illustrerer en sjelden, men livstruende manifestasjon av tuberkulose. Kombinasjonen av klinisk undersøkelse, anamneseopptak, radiologiske unders $\emptyset$ kelser og epidemiologisk tankegang ga mistanke om tuberkulose i sentralnervesystemet. Pasientens symptomer med hodepine, svimmelhet og dobbeltsyn samt de kliniske funnene i form av hjernenerveutfall og ataksi skyldtes tuberkulomer i hjernestamme og lillehjerne. Dette er en sjelden tilstand i Norge, men forekommer oftere hos pasienter med opprinnelse fra eller opphold i et høyendemisk land.

Siden direkte mikroskopi har lav sensitivitet og vekst av mykobakterier kan ta inntil seks uker, er det i alvorlige tilfeller ofte nødvendig å starte behandling før diagnosen tuberkulose er bekreftet. PCR kan være nyttig for å påvise tuberkulosebakterien ved negativ mikroskopi og kan også gi informasjon om antibiotikafølsomhet ved genotypisk resistensbestemmelse. Ved påvist mutasjon som tyder på resistens mot rifampicin, må man anta at det er høy sannsynlighet for samtidig isoniazidresistens. Kombinasjonen av resistens mot både rifampicin og isoniazid definerer multiresistent tuberkulose, som krever svært langvarig og potensielt toksisk behandling. PCR-metoden for resistenspåvisning er ikke validert for å brukes direkte på prøvemateriale. I dette tilfellet førte den til at denne pasienten fikk unødig behandling med bivirkningsbeheftede reservemedisiner. Vi valgte likevel å gjøre denne undersøkelsen fordi det ved lesjoner i sentralnervesystemet er viktig å få svar så raskt som mulig, da riktig behandling er livreddende. Fenotypisk resistensbestemmelse har bedre sensitivitet og spesifisitet og gir også resistensresultater for flere medikamenter. Vår pasient kunne derfor gå tilbake til førstelinjemedikamenter idet prøven avkreftet multiresistent tuberkulose. 
Ved mistenkt ekstrapulmonal tuberkulose er det viktig å sikre prøvemateriale, og biopsi av flere lokalisasjoner kan være nødvendig for å øke diagnostisk treffsikkerhet. Diagnostikk ved hjernebiopsi er krevende og innebærer risiko for alvorlige komplikasjoner. Siden tuberkulose i hjernen er uttrykk for lymfohematogen spredning av mykobakterier, er det viktig å undersøke hvorvidt det foreligger ekstrakranial sykdom. Om lag tre firedeler av pasientene med tuberkulose i sentralnervesystemet har ekstrakraniale lesjoner som kan være lettere tilgjengelig for diagnostikk (5). Vår pasient hadde lesjoner i både lunge, nyre, lever og prostata, og prøvetagning fra disse organene innebar mindre risiko enn hjernebiopsi. Etter negative prøver fra både luftveissekret, urin og avføring samt CT-veiledet biopsi av lungeforandringer, var det biopsi fra prostata som til slutt bekreftet diagnosen.

Sykehistorie og funn illustrerer viktige poeng i diagnostikk av tuberkulose. Det er all grunn til å være årvåken overfor denne gamle, men fortsatt like relevante sykdommen.

\section{LITTERATUR:}

1. Folkehelseinstituttet. Tuberkoloseveiledningen: Behandling av tuberkulose. https://www.fhi.no/nettpub/tuberkuloseveilederen/utredning-og-behandling/behandling-av-tuberkul ose/\#91-medikamentell-behandling (2.6.2018).

2. Vinnard C, Winston CA, Wileyto EP et al. Isoniazid resistance and death in patients with tuberculous meningitis: retrospective cohort study. BMJ 2010;341: c4451. [PubMed][CrossRef]

3. Ruslami R, Ganiem AR, Dian S et al. Intensified regimen containing rifampicin and moxifloxacin for tuberculous meningitis: an open-label, randomised controlled phase 2 trial. Lancet Infect Dis 2013; 13: 27-35. [PubMed][CrossRef]

4. Thwaites GE, Lan NT, Dung NH et al. Effect of antituberculosis drug resistance on response to treatment and outcome in adults with tuberculous meningitis. J Infect Dis 2005; 192: 79 - 88. [PubMed][CrossRef]

5. Kennedy DH, Fallon RJ. Tuberculous meningitis. JAMA 1979; 241: 264 - 8. [PubMed][CrossRef]

Publisert: 26. september 2018. Tidsskr Nor Legeforen. DOI: 10.4045/tidsskr.17.0801

Mottatt 17.9.2017, første revisjon innsendt 9.11.2017, godkjent 25.6.2018.

(C) Tidsskrift for Den norske legeforening 2020. Lastet ned fra tidsskriftet.no 